\title{
УДК621.791.3
}

DOI 10.33082/2226-1915 -2-2019-107-120

\section{РОЗРОБКА ПРИПОЮ ДЛЯ ПАЯННЯ ЖАРОМІЦНИХ НІКЕЛЕВИХ СПЛАВІВ СУДНОВИХ ГАЗОВИХ ТУРБІН}

Б.В. Бугаснко

канд.техн.наук, доцент

С.А. Бутурля

аспірант

О.М. Костін

канд.техн.наук, професор

Національний університет кораблебудування ім. адм. Макарова

Анотація. Легування сплавів ренієм $i$ танталом дозволило розробити нові сплави СМ 93 і СМ 96, щзо дозволило підвищити робочу температуру газу морських газотурбінних двигунів (ГТД) на 40-60 ${ }^{\circ} \mathrm{C} \mathrm{ma}$ забезпечити стійкість до високотемпературної сольової корозії (ВСК). Припій SBM-3 використовується для паяння авіаиійних ЖНС. Для можливості його використання для паяння суднових ГТД запропоновано знизити температуру паяння введенням депресанту Si через припій HC-12. Si підвищує також стійкість до ВCК. До складу SBM-3 додавалось 10, 20 та $30 \%$ мас. НC-12. Додавання припою НC-12 до SBM-3 при незмінній температурі паяння збільшує площу розтікання припою по поверхні СМ 93 при температурі $1200{ }^{\circ} \mathrm{C}$ від 40 до $50 \mathrm{Mм}^{2}$; при температурі $1220{ }^{\circ} \mathrm{C}$ від 60 до $100 \mathrm{Mм}^{2}$; при температурі $1240{ }^{\circ} \mathrm{C}$ від 180 до $205 \mathrm{Mм}^{2}$. Площа розтікання припою зростає в 4-4,5 рази з підвищенням температури паяння від 1200 до $1240{ }^{\circ} \mathrm{C}$ для всіх досліджуваних сумішей припою SBM-3 з НС-12. Крайовий кут змочування зменшується при збільшенні кониентраиії HC-12 від 10 до 30 \% мас. В припої SBM-3: при темпера-турі $1220{ }^{\circ} \mathrm{C}$ від 6,3 ${ }^{\circ}$ до $4{ }^{\circ}$; при температурі $1240{ }^{\circ} \mathrm{C}$ від $4,8^{\circ}$ до 3,3 ${ }^{\circ}$, а при температурі $1200{ }^{\circ} \mathrm{C}$ він складає приблизно $7{ }^{\circ}$. При підвищенні температури паяння від $1200{ }^{\circ} \mathrm{C}$ до $1240{ }^{\circ} \mathrm{C}$ крайовий кут змочування зменшується: при $10 \%$ мас. НС-12 з 7,5 ${ }^{\circ}$ до 4,8 ${ }^{\circ}$; при $20 \%$ мас. HC-12 з 6,5 ${ }^{\circ}$ до 4,0 ${ }^{\circ}$; при $30 \%$ мас. $\mathrm{HC}-12$ з 7,5 ${ }^{\circ}$ до 4,0 ${ }^{\circ}$. Розподіл Si по висоті краплі в діаметральній ї̈ площині не рівномірний. При температурі паяння $1200{ }^{\circ} \mathrm{C}$ на межі з основним металом Si відсутній, його концентрація зростає по висоті краплі і досягає максимального значення на їі поверхні $12,71 \%$ мас. (добавка НС-12 - 30 \% мас.) Або в ї̈ иентральній частині 2,64\% мас. (добавка НС-12 - $10 \%$ мас.) ) і 6,39\% мас. (добавка НС-12 - 20 \% мас.). При температурі паяння $1220-1240^{\circ} \mathrm{C}$ максимальна кон-иентрація Si спостерігається, майже на середині висоти краплі.

\section{() Бугаенко Б.В., Бутурля Є.А., Костін О.М., 2019}


ВІСНИК

ОДЕСЬКОГО НАЦІОНАЛЬНОГО

МОРСЬКОГО УНІВЕРСИТЕТУ

№ 2 (59), 2019
HERALD

OF THE ODESSA NATIONAL

MARITIME UNIVERSITY № 2 (59), 2019

3 підвищенням температури паяння понад $1200{ }^{\circ} \mathrm{C}$ спостерігається розчинення основного металу в припої, а також Si в основному металі на межі припій-основний метал.

Ключові слова: припій; крайовий кут змочування; розтікання припою; жароміцчний сплав.

УДК621.791.3

DOI 10.33082/2226-1915 -2-2019-107-120

\title{
РАЗРАБОТКА ПРИПОЯ ДЛЯ ПАЙКИ ЖАРОПРОЧНЫХ НИКЕЛЕВЫХ СПЛАВОВ ДЛЯ СУДОВЫХ ГАЗОВЫХ ТУРБИН
}

\author{
Б.В. Бугаенко \\ канд.техн.наук, доцент \\ Е.А. Бутурля \\ аспирант \\ А.М. Костин \\ канд.техн.наук, профессор
}

Национальный университет кораблестроения им. адм. Макарова

Аннотация. Легирование сплавов рением и танталом позволило разработать новые сплавы СМ 93 и СМ 96, что позволило повысить рабочую температуру газа морских газотурбинных двигателей (ГТД) на 40-60 ${ }^{\circ} \mathrm{C}$ и обеспечить устойчивость к высокотемпературной солевой коррозии (ВСК). Припой SBM-3 разработан для пайки ЖНС. Для возможности его использования для пайки судовых ГТД предложено снизить температуру пайки введением депрессантов Si через припой HC-12. Si повышает также устойчивость к BCK. В состав SBM-3 добавлялось 10, 20 и 30 \% масс. НC-12. Добавление припоя HC-12 к SBM-3 при неизменной температуре пайки увеличивает площадь растекания припоя по поверхности СМ 93 при температуре $1200{ }^{\circ} \mathrm{Com} 40$ до $50 \mathrm{Mм}^{2}$; при температуре $1220{ }^{\circ} \mathrm{C}$ от 60 до $100 \mathrm{Mм}^{2}$; при температуре $1240{ }^{\circ} \mathrm{C}$

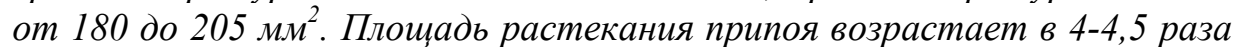
с повышением температуры пайки от 1200 до $1240{ }^{\circ} \mathrm{C}$ для всех исследуемых смесей припоя SBM-3 с НС-12. Краевой угол смачивания уменьшается при увеличении кониентрачии НС-12 от 10 до 30 \% масс. В nрипое SBM-3: при температуре $1220{ }^{\circ} \mathrm{C}$ от 6,3 ${ }^{\circ}$ до $4^{\circ}$; при темпеpamype $1240^{\circ} \mathrm{C} \mathrm{om} 4,8^{\circ}$ до $3,3^{\circ}$, а при температуре $1200{ }^{\circ} \mathrm{C}$ он составляет примерно 7 ․ При повышении температуры пайки от $1200{ }^{\circ} \mathrm{C}$ до $1240{ }^{\circ} \mathrm{C}$ краевой угол смачивания уменьшается: при $10 \%$ масс. НС-12 с 7,5 ${ }^{\circ}$ до 4,8 ${ }^{\circ}$; при $20 \%$ масс. HC- 12 с 6, $5^{\circ}$ до 4,0 ${ }^{\circ}$; при $30 \%$ масс. HC-12 c 7,5 ${ }^{\circ}$ до 4,0 ${ }^{\circ}$. Распределение Si по высоте капли в диаметральной ее плоскости не равномерен. При температуре пайки $1200{ }^{\circ} \mathrm{C}$ на границе $c$ основным металлом Si отсутствует, его кониент-раџия возрастает по 
высоте капли и достигает максимального значения на ее поверхности $12,71 \%$ масс. (добавка НС-12-30\% масс.) Или в ее иентральной части 2, $64 \%$ масс. (добавка НС-12-10\% масс.) и 6,39\% масс. (добавка НС-1220\% масс.). При температуре пайки 1220-1240 ${ }^{\circ} \mathrm{C}$ максимальная концентрация Si наблюдается почти на середине высоты капли.

C повышением температуры пайки более $1200{ }^{\circ} \mathrm{C}$ наблюдается растворение основного металла в припое, а также Si в основном металле на грани припой-основной металл.

Ключевые слова: припой; краевой угол, смачивание, растекание припоя, жаропрочный сплав.

UDC 621.791.3

DOI 10.33082/2226-1915 -2-2019-107-120

\title{
DEVELOPMENT OF SOLDER TO SOLDER HEAT RESISTING NICKEL ALLOYS FOR MARINE GAS TURBINES
}

\author{
B.V. Bugaenko \\ cand. of technical Sciences, docent \\ E.A. Buturlia \\ postgraduate student \\ A.M. Kostin \\ cand. of technical Sciences, professor \\ Admiral Makarov National University of Shipbuilding
}

The alloying of alloys with rhenium and tantalum allowed the development of new alloys CM 93 and CM 96, which made it possible to raise the operating temperature of the gas of marine gas turbine engines (GTE) by 40-60 ${ }^{\circ} \mathrm{C}$ and ensure resistance to high-temperature salt corrosion (HTSC). Solder SBM-3 is designed for soldering GTE. In order to be able to use it for soldering marines GTE, it has been proposed to reduce the brazing temperature by introducing Si depressants through NS-12 solder. Si also increases resistance to HTSC. The composition of SBM-3 was added 10, 20 and $30 \%$ of the mass. NS-12. Adding NS-12 solder to SBM-3 at a constant brazing temperature increases the solder spreading area over the CM 93 surface at $1200{ }^{\circ} \mathrm{C}$ from 40 to $50 \mathrm{~mm}^{2}$; at a temperature of $1220{ }^{\circ} \mathrm{C}$ from 60 to $100 \mathrm{~mm}^{2}$; at a temperature of $1240{ }^{\circ} \mathrm{C}$ from 180 to $205 \mathrm{~mm}^{2}$. The spreading area of the solder increases $4-4,5^{\circ}$ times with an increase in the soldering temperature from 1200 to $1240{ }^{\circ} \mathrm{C}$ for all the tested solder compounds SBM-3 with NS-12. Wetting angle decreases with increasing concentration of NC-12 from 10 to $30 \%$ of the mass. In SBM-3 solder: at a temperature of $1220^{\circ} \mathrm{C}$ from 6,3 ${ }^{\circ}$ to $4^{\circ}$; at a temperature of $1240^{\circ} \mathrm{C}$ from $4,8^{\circ}$ to $3,3^{\circ}$, and at a temperature of $1200^{\circ} \mathrm{C}$ it is approximately $7^{\circ}$. With an increase in brazing temperature from $1200^{\circ} \mathrm{C}$ to $1240^{\circ} \mathrm{C}$, the wetting angle decreases: at $10 \%$ 
of the mass. NS- 12 from $7,5^{\circ}$ to $4,8^{\circ}$; at $20 \%$ of the mass. NS- 12 from $6,5^{\circ}$ to $4,0^{\circ}$; at $30 \%$ of the mass. NS-12 from $7,5^{\circ}$ to $4,0^{\circ}$. The distribution of Si over the height of a drop in its diametral plane is uneven. At a brazing temperature of $1200^{\circ} \mathrm{C}$ at the boundary with the base metal Si, its concentration increases along the height of the drop and reaches a maximum value on its surface of $12,71 \% \mathrm{wt}$. (addition of NS-12-30\% of the mass.) Or in its central part 2, 64 $\%$ of the mass. (addition of HC-12-10\% of the mass.) and $6.39 \%$ of the mass. (additive NS-12 - $20 \%$ of the mass.). At a soldering temperature of 1220-1240 ${ }^{\circ} \mathrm{C}$, the maximum concentration of $\mathrm{Si}$ is observed almost in the middle of the drop height. With an increase in the soldering temperature of more than 1200 ${ }^{\circ} \mathrm{C}$, the dissolution of the base metal in the solder, as well as $\mathrm{Si}$ in the base metal on the verge of the solder-base metal, is observed

Keywords: marine gas turbine; solder; wetting angle; spreading solder; heat-resistant alloy.

Актуальність проведення досліджень. Удосконалення газотурбінних двигунів (ГТД) спрямоване на підвищення робочих температур і ресурсу їх роботи [1]. Поряд з удосконаленням конструкції турбін важливим напрямком $є$ розробка жароміцних сплавів для турбін нового покоління [2; 3]. Основним конструкційним матеріалом для виготовлення морських і авіаційних ГТД є жароміцні нікелеві сплави (ЖНС). При їх зварюванні плавленням утворюються гарячі тріщини через втрати пластичності в температурному інтервалі крихкості $1200-1220{ }^{\circ} \mathrm{C}$ [1]. Ливарні ЖНС відносяться до класу дисперсійно-твердіючих високотемпературних матеріалів [2]. Найбільш універсальним способом з’єднання ЖНС та виправлення ливарних дефектів $€$ паяння.

Морські ГТД працюють в умовах високотемпературної сольової корозії (ВСК), дія якої в десятки і сотні раз інтенсивніша порівняно зі стандартними умовами роботи авіаційних турбін [4] Сучасна задача, поставлена конструкторами морських турбін щодо підвищення ефективності і робочої температури газу, вимагає підвищення жароміцності сплавів морських турбін, що дозволяє підвищити температуру паяння сплавів.

В роботі [4] показано, що легування сплавів ренієм і танталом дозволило розробити нові сплави СМ93 і СМ96 для морських турбін, а оптимізація хімічного складу, структури і термічної обробки дозволяють підвищити робочу температуру газу на $40-60{ }^{\circ} \mathrm{C}$, і відповідно підвищити температуру аустенізації сплавів. Об'ємний вміст $\gamma^{\prime}$-фази в сплаві СМ 93-ВI складає 55,2 \% ат., вміст карбідів і боридів дорівнює 2,2 \% ат.

Підвищення температури аустенізації сплавів дозволяє розробити припої з підвищеною температурою паяння. До таких припоїв відноситься припій SBM-3 [5]. 
ВІСНИК

ОДЕСЬКОГО НАЦІОНАЛЬНОГО

МОРСЬКОГО УНІВЕРСИТЕТУ № 2 (59), 2019
HERALD

OF THE ODESSA NATIONAL

MARITIME UNIVERSITY № 2 (59), 2019

3 урахуванням ВСК традиційні сплави суднових ГТД мають концентрацію хрому до 18 \%. Підвищений вміст $\mathrm{Cr}$ знижує жароміцність сплаву. Для підвищення жароміцності сплави легують рядом елементів [4; 6]. Робочі температури суднових ГТД нижчі авіаційних. Припій SBM-3 розроблено для нових сплавів морських турбін. Для можливості його використання під час паяння сучасних суднових ГТД необхідно знизити температуру плавлення припою. Цього можна досягти введенням в припій SBM-3 додатково депресантів, наприклад, додаванням до його складу $\mathrm{Si}$. Кремній вводиться в припій шляхом додавання до його складу припою НС-12, розробленого в НУК [1].

Аналіз останніх досліджень і публікацій. В роботі [4] для морських турбін нового покоління розроблено припій SBM-3 з температурою паяння $1210-1230{ }^{\circ} \mathrm{C}$, але для сучасних сплавів допустима температура короткочасного нагрівання складає $1210{ }^{\circ} \mathrm{C}$. Розроблені перспективні припої для авіаційних турбін ВПр36, ВПр37, ВПр44 мають температуру паяння 1250-1300 ${ }^{\circ} \mathrm{C}$ і не придатні для паяння ЖНС суднових турбін. Тому зниження температури паяння припоєм SBM-3 для сучасних сплавів $\epsilon$ актуальним для суднового газотурбобудування. Цей припій забезпечує значно вищу жароміцність з'єднань, ніж використовувані припої ВПр 11-40H i HC-12.

Оскільки лопатки авіаційних газових турбін працюють при більш високих температурах, то відповідно їх сплави мають більшу жароміцність, що дозволяє використовувати для паяння припої з вищою температурою плавлення і відповідно паяння. Наприклад, для сплавів ЖС 36 , ЖС 32, ЖС40, ВЖМ4 рекомендовано припої ВПр36, ВПр37, ВПр44, основою яких є системи Ni-Cr-Co-Al-Mo-W-Nb-B (BПр36), Ni-Cr-Al-TiW-B (BПр37), i Ni-Cr-Co-Al-Mo-W-B (BПр44) 3 температурами паяння 1250-1300 ${ }^{\circ} \mathrm{C}$, що призводить до знеміцнення основного металу.

Для зниження температури паяння автори роботи [9] для паяння сплаву ЖС6У використовували композиційний припій, який складається 3 припою ВПр36, припою НС-12, припою на основі нікелю, що містить (\%, мас.): 9,0 Cr; $14,0 \mathrm{Co} ; 3,8 \mathrm{Al} ; 2,5 \mathrm{~B}$, а в якості наповнювача застосовували сплави Rene142 і ЖС32.

В роботі [9] зазначено, що ВПр36 широко застосовується в авіаційному турбобудуванні ЗМКБ «Прогрес» при температурі паяння $1250-1265{ }^{\circ} \mathrm{C}$ та тривалості 20 хв. при цьому в шві виділяються крупні карбоборидні фази $\mathrm{Me}(\mathrm{C}, \mathrm{B})$ на основі $\mathrm{Nb}, \mathrm{W}$, стабільні при високій температурі, частки неправильної форми карбіду $\mathrm{Me}_{6} \mathrm{C}$, крім того спостерігаються також борвмісні евтектики. Це $\epsilon$ причиною крихкого руйнування. Для підвищення технологічної пластичності паяних з'єднань застосовувались борвмісні припої, але ці припої піддаються катастрофічній корозії в умовах роботи суднових турбін. Суть даної роботи полягає в 
легуванні припою SBM-3 припоєм НC-12, що має підвищену стійкість до BCK [1].

Постановка завдання. Дослідити можливість використання припою SBM-3 під час паяння жароміцних нікелевих сплавів в суднових ГТД. Дослідити поверхневі властивості припою і його хімічну взаємодію з основним металом.

Викладення основного матеріалу дослідження. Для виготовлення лопаток морських турбін використовують ливарні сплави. Лопатки відливають у вакуумі методом точного лиття. Перспективним є сплав СМ 93, хімічний склад якого наведений в табл.1. В цій же таблиці наведений хімічний склад припою SBM-3, який розроблено для паяння ливарних жароміцних сплавів морських ГТД нового покоління.

Таблиия 1

Хімічний склад ЖНС СM93 і системи припою SBM-3

\begin{tabular}{|c|c|c|c|c|c|c|c|c|c|c|}
\hline \multirow{2}{*}{$\begin{array}{c}\text { Номер } \\
\text { 3/п }\end{array}$} & \multirow{2}{*}{ Сплав } & \multicolumn{10}{|c|}{ Хімічний склад, \% мас. } \\
\cline { 3 - 12 } & & $\mathrm{C}$ & $\mathrm{Ni}$ & $\mathrm{Cr}$ & $\mathrm{Mo}$ & $\mathrm{W}$ & $\mathrm{Nb}$ & $\mathrm{Ti}$ & $\mathrm{Al}$ & $\mathrm{Co}$ \\
\hline \multirow{2}{*}{1} & \multirow{2}{*}{ СМ93 } & $0,08-$ & \multirow{2}{*}{ Осн. } & $12,3-$ & $0,8-$ & $4,3-$ & $0,1-$ & $4,6-$ & $2,8-$ & $6,7-$ \\
& 0,12 & & 12,8 & 1,2 & 4,7 & 0,3 & 5,0 & 3,2 & 7,3 \\
\hline 2 & SBM-3 & 0,10 & Ocн. & + & + & + & & & + & + \\
\hline
\end{tabular}

Продовження табл.1

\begin{tabular}{|c|l|c|c|c|c|c|c|c|c|}
\hline \multirow{2}{*}{$\begin{array}{c}\text { Номер } \\
\text { з/п }\end{array}$} & \multirow{2}{*}{ Сплав } & \multicolumn{7}{|c|}{ Хімічний склад, \% мас. } \\
\cline { 3 - 10 } & & $\mathrm{Fe}$ & $\mathrm{Zr}$ & $\mathrm{Ta}$ & $\mathrm{Re}$ & $\mathrm{Si}$ & $\mathrm{B}$ & $\mathrm{Mn}$ & $\mathrm{Hf}$ \\
\hline \multirow{2}{*}{1} & \multirow{2}{*}{ СМ93 } & $<0,5$ & $\begin{array}{c}0,02- \\
0,06\end{array}$ & $3,3-3,6$ & $2,4-2,8$ & 0,3 & $\begin{array}{c}0,04- \\
0,08\end{array}$ & 0,3 & \\
\hline 2 & SBM-3 & & & + & + & & + & & + \\
\hline
\end{tabular}

Для з'єднання ЖНС СМ 93 паянням деталей морських газових турбін 3 температурою паяння $1220{ }^{0} \mathrm{C} \pm 10{ }^{\circ} \mathrm{C}$ пропонується зменшити температуру паяння припоєм SBM-3 додаванням до його складу в якості депресанта кремнію через його легування припоєм $\mathrm{HC}-12$ (склад HC-12 - 12,1 \% мас. $\mathrm{Si}$; $\mathrm{Ni}$ - осн.) Для виконання процесу паяння припої повинні змочувати основний метал, розтікатися по його поверхні та затікати в зазори. Проводились дослідження впливу вмісту НС-12 в припої SBM-3 та температури паяння на площу розтікання припою по 
поверхні жароміцного ливарного нікелевого сплаву СМ 93 при різних температурах паяння.

Розтікання досліджувалось на зразках по поверхні, шліфованій в одному напрямку. В якості припою використовувалась механічна суміш порошків припою SBM-3 та НC-12. Вміст легувального припою НС-12 складав $10 \%, 20 \%$ та $30 \%$ мас., тобто в припій додавалось 1,21 \%, 2,42\% та 3,63 \% Si мас. відповідно. Для кожного досліду маса навішення припою складала $100 \mathrm{Mг} \pm 1 \mathrm{Mг}$. Перед нанесенням припою поверхня зразків знежирювалась спиртом. Зважаючи на те, що використовувались припої в поропошкоподібному стані для закріплення їх на поверхні зразків використовувався розчин бутакрилової смоли. Смола в процесі нагрівання випаровувалась i, таким чином, не змінювала складу припою та не впливала на результати досліджень.

Підготовлені зразки завантажувались в електричну вакуумну піч 3 радіаційним нагріванням СНВ - 1.3.1/20И1. Після досягнення в печі залишкового тиску $10^{-2}$ Па, розпочиналось нагрівання зразків. Контроль температури здійснювався двома термопарами платинородій-платина закріплених на контрольних дисках масою 10г. В процесі нагрівання температура автоматично записувалась на комп'ютері.

В кожному досліді середня швидкість нагрівання складала $8{ }^{0} \mathrm{C} /$ хв., тривалість витримки при температурі паяння зразків складала 15 хв. Охолодження проходило разом з охолодженням печі зі швидкістю в середньому $7{ }^{0} \mathrm{C} / \mathrm{xв}$.

Був складений план досліджень зразків, наведений в табл. 2,

де $\mathrm{X}_{1}, \mathrm{X}_{2}, \mathrm{X}_{3}$ - вміст НC-12 в припої SBM-3;

$\mathrm{X}_{4}, \mathrm{X}_{5}, \mathrm{X}_{6}$ - температура паяння;

$\mathrm{Y}_{1}-$ крайовий кут змочування;

$\mathrm{Y}_{2}$ - площа розтікання.

Таблиия 2

\section{План проведення досліджень}

\begin{tabular}{|c|c|c|c|c|c|c|}
\hline $\mathrm{X}_{1}$ & $\mathrm{X}_{2}$ & $X_{3}$ & $X_{4}$ & $\mathrm{X}_{5}$ & $\mathrm{X}_{6}$ & \\
\hline 1 & 0 & 0 & \multirow{3}{*}{1} & \multirow{3}{*}{1} & \multirow{3}{*}{1} & $Y_{1}$ \\
\hline 0 & 1 & 0 & & & & $Y_{1}$ \\
\hline 0 & 0 & 1 & & & & $Y_{1}$ \\
\hline 1 & 0 & 0 & \multirow{3}{*}{1} & \multirow{3}{*}{1} & \multirow{3}{*}{1} & $\mathrm{Y}_{2}$ \\
\hline 0 & 1 & 0 & & & & $Y_{2}$ \\
\hline 0 & 0 & 1 & & & & $\mathrm{Y}_{2}$ \\
\hline
\end{tabular}

Після термічного циклу паяння проводилась обробка результатів дослідів. Фотографувалися зразки, за отриманими фото визначалась площа розтікання припою (рис. 1). 

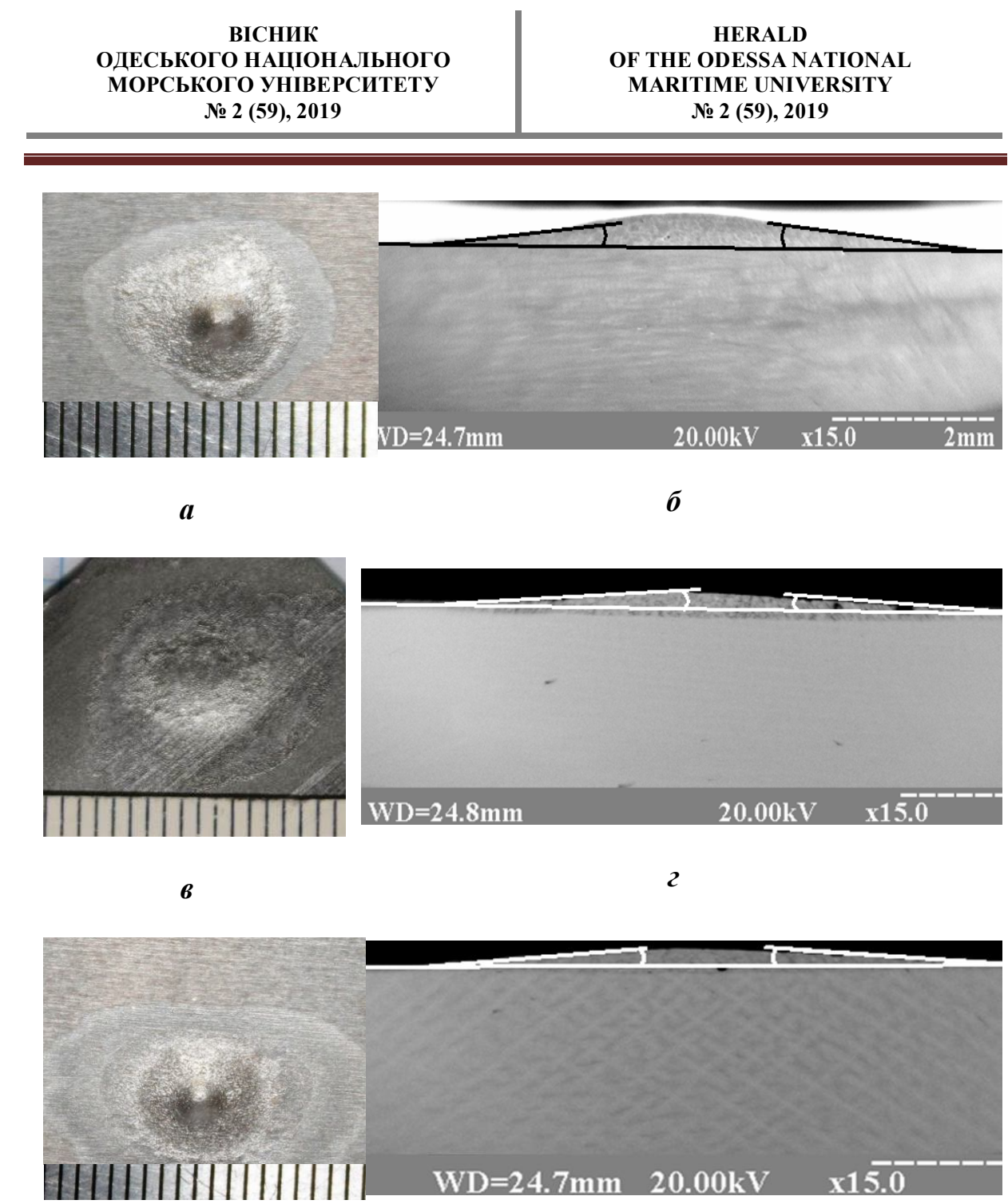

ठ

$\boldsymbol{e}$

Рис. 1. Дослідження площі розтікання $(\boldsymbol{a}, \boldsymbol{b}, \boldsymbol{\partial})$ та крайового кута змочування $(\boldsymbol{\sigma}, \boldsymbol{2}, \boldsymbol{e})$ припоєм SBM-3 + HC-12 поверхні жароміиного нікелевого сплаву при температурі паяння $1220^{\circ}$, вміст HC-12, a, $\boldsymbol{\sigma}-10 \%, \boldsymbol{b}, \boldsymbol{z}-20 \%, \boldsymbol{d}, \boldsymbol{e}-30 \%$

На підставі проведених досліджень після статистичної обробки побудовані залежності площі розтікання припою по поверхні зразка від вмісту легувального припою НC-12 в припої SBM-3 при різних температурах та температури паяння при додаванні $10 \%, 20 \%$ та $30 \%$ мас. HC-12 до припою SBM-3 (рис. 2). 
ВІСНИК

ОДЕСЬКОГО НАЦІОНАЛЬНОГО МОРСЬКОГО УНІВЕРСИТЕТУ
HERALD

OF THE ODESSA NATIONAL

MARITIME UNIVERSITY

№ 2 (59), 2019

a)

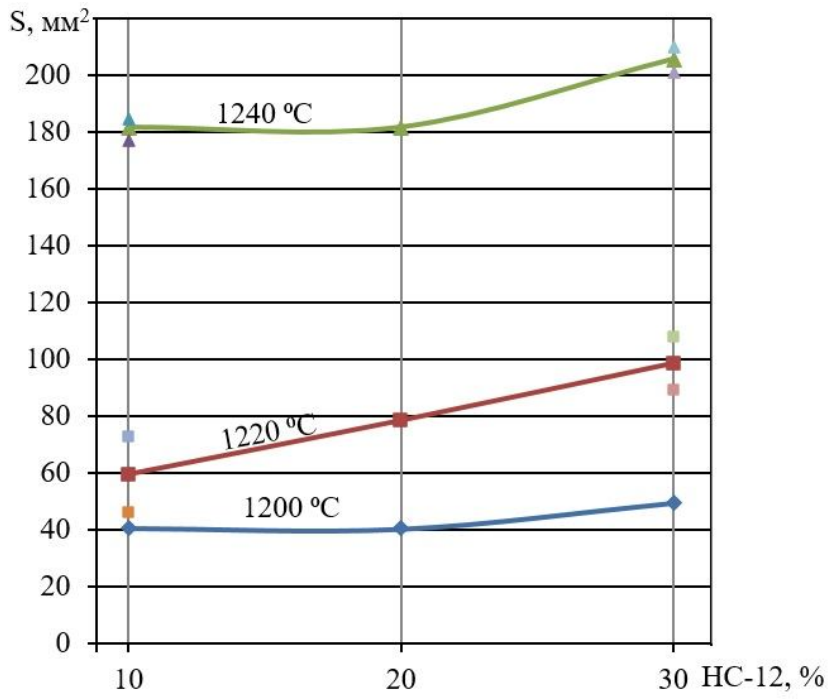

б)

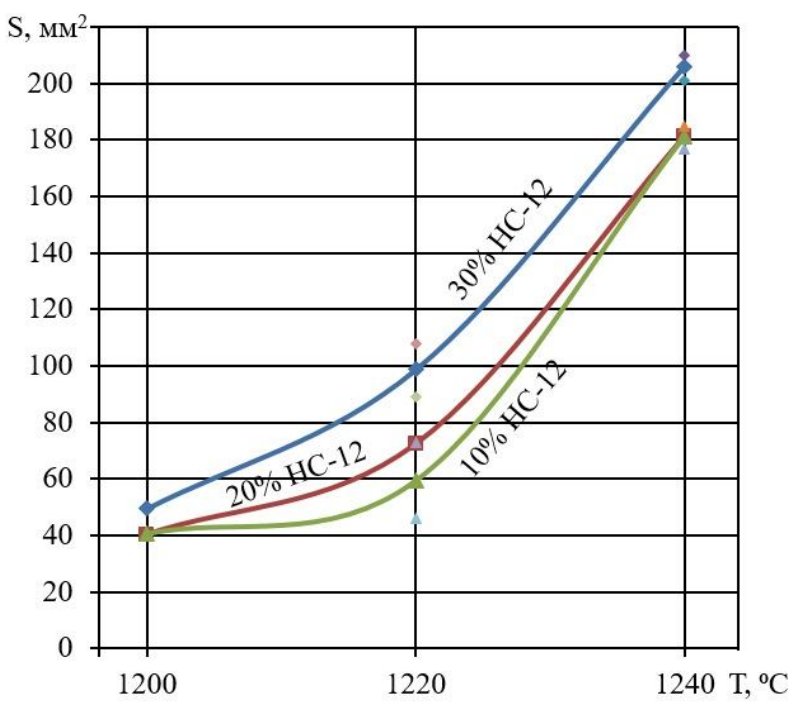

Рис. 2. Вплив вмісту НС-12 (a)

i температури паяння (б) на площу розтікання припою SBM-3 по поверхні жаромічного нікелевого сплаву CM 93 
ВІСНИК

ОДЕСЬКОГО НАЦІОНАЛЬНОГО МОРСЬКОГО УНІВЕРСИТЕТУ № 2 (59), 2019
HERALD

OF THE ODESSA NATIONAL

MARITIME UNIVERSITY № 2 (59), 2019

Для подальшого дослідження зразки розрізалися по діаметральній площині точки припою, виготовлялися макрошліфи для визначення впливу складу припою та температури паяння на крайовий кут змочування припоєм поверхні ЖНС. На підставі отриманих результатів побудовані залежності крайового кута змочування припоєм SBM-3 + HC-12 в залежності від вмісту легувального припою НC-12 в припої SBM-3 та від температури паяння (рис. 3).

a)

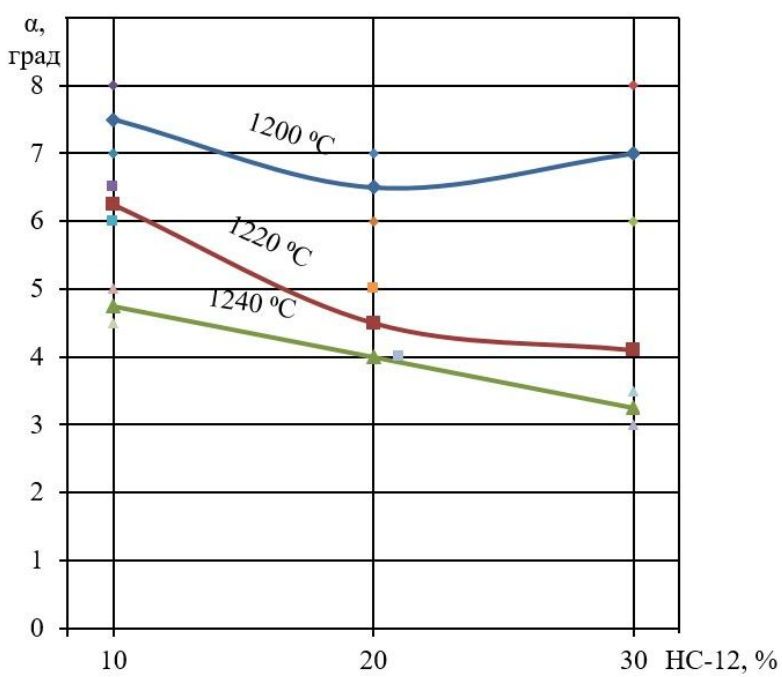

б)

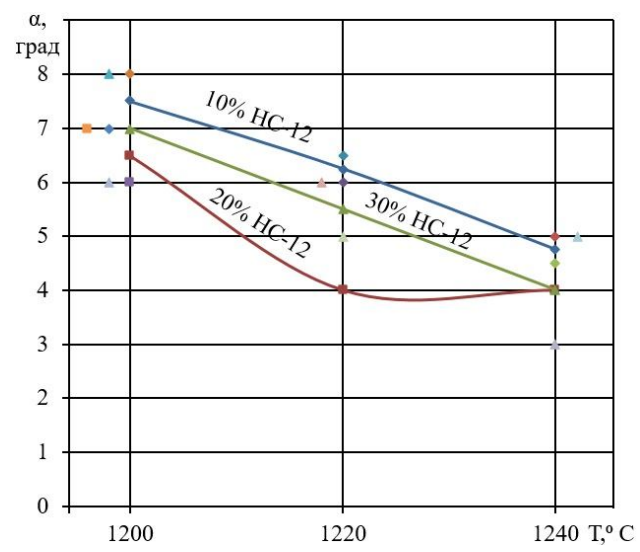

Рис. 3. Вплив вмісту HC-12 в припої SBM-3 (a) і температури паяння (б) на крайові кути змочування припоєм SВM-3 жароміцного нікелевого сплаву СM 93 
Із отриманих залежностей видно, що додавання 10-30 \% мас. припою НC-12 до припою SBM-3 при незмінній температурі паяння сприяє збільшенню площі розтікання припою по поверхні досліджуваного жароміцного сплаву (рис. 2, a): при температурі $1200^{\circ}$ від 40 до $50 \mathrm{Mм}^{2}-$ площа розтікання зростає на $25 \%$; при температурі $1220{ }^{0}$ від 60 до $100 \mathrm{mм}^{2}$ - площа розтікання зростає майже на $67 \%$; при температурі $1240{ }^{0}$ від 180 до 205 мм $^{2}$ - площа розтікання зростає на $19 \%$.

За результатами досліджень рекомендовано добавку 20-30 \% припою НC-12 до припою SBM-3. Аналогічні добавки рекомендовані авторами робіт $[10 ; 11]$ для зниження температури плавлення припою ВПр36.

В той же час, температура паяння більш суттєво впливає на площу розтікання (рис. 2, б). Площа розтікання припою по поверхні жароміцного сплаву зростає в 4-4,5 рази з підвищенням температури паяння від $1200^{\circ}$ до $1240^{\circ}$ для всіх досліджуваних сумішей припою SBM-3 з НC-12. Розтікання припою збільшується вздовж ліній на поверхні зразків отриманих під час підготовки їх до паяння шліфуванням.

Із отриманих залежностей видно, що крайовий кут змочування зменшується при збільшенні концентрації НC-12 в припої SBM-3 (рис. 3, a): при температурі $1220^{0}$ від $6,3^{0}$ до $4^{0}$; при температурі $1240{ }^{\circ}$ від $4,8^{0}$ до $3,3^{0}$, а при температурі $1200^{\circ}$ крайовий кут змочування практично не змінюється і складає приблизно $7^{0}$. Температура паяння суттєво впливає на крайовий кут змочування жароміцного нікелевого сплаву сумішшю припоїв SBM-3 + НC-12 Припій з вмістом $10 \%$ мас. НC12 при температурі паяння $1200^{0}$ має крайовий кут змочування 7,5 ${ }^{0}$, а при $1240^{\circ}-4,8^{0}$. Припій з вмістом $20 \%$ мас. НС-12 забезпечує крайовий кут змочування $6,5^{0}$ при температурі $1200^{\circ}$, а при $1220^{\circ}$ він складає $4^{0}$. Припій $з$ вмістом $30 \%$ мас. НС-12 забезпечує крайовий кут змочування $7,5^{\circ}$ при температурі $1200^{\circ}$, а при $1240^{\circ}$ він зменшується до $4^{0}$.

Для вивчення структури краплі припою, взаємодії припою 3 основним металом та розподілу легувальних елементів по висоті і поверхні краплі підготовлені мікрошліфи на поверхні площини діаметрального розрізу краплі.

Для оцінки розподілу елементів припою і основного металу проводився локальний рентгеноспектральний мікроаналіз на PEMМА102-02А, що необхідно для встановлення закономірностей розподілу елементів внаслідок легування припою кремнієм через додавання його в складі припою НС-12 та взаємодії припою з основним металом.

Розподіл кремнію по висоті краплі в діаметральній ії площині не рівномірний. Його концентрація залежить від вмісту припою НС-12 та температури паяння.

При температурі паяння $1200{ }^{0} \mathrm{C}$ на межі 3 основним металом кремній відсутній, його концентрація зростає по висоті краплі і досягає 
максимального значення на іï поверхні 12,71 \% мас. (добавка НС-12 $30 \%$ мас.) або в іiі центральній частині 2,64\% мас. (добавка НС-12 $10 \%$ мас.) і 6,39 \% мас. (добавка НС-12 - 20 \% мас.). При температурі паяння 1220-1240 ${ }^{0} \mathrm{C}$ максимальна концентрація кремнію спостерігається майже на середині висоти краплі. При цьому, з підвищенням температури паяння понад $1200{ }^{0} \mathrm{C}$ спостерігаються розчинення основного металу в припої, а також кремній на межі припій-основний метал.

\section{Висновки}

1. ЖНС в морських ГТД працюють в агресивному середовищі, що потребує застосовувати сплави та припої здатні протистояти ВСК на рівні основного металу.

2. Для використання в морських ГТД авіаційного припою SBM-3 його температура паяння може знижуватися введенням додаткового депресанта кремнію, який підвищує стійкість до ВСК.

3. За результатами експериментальних досліджень рекомендується для паяння сплаву СМ 93 при температурі до1220 ${ }^{0} \mathrm{C}$ припій SBM-3 3 додаванням до його складу 20 \% мас. припою НС-12.

\section{СПИСОК ЛІТЕРАТУРИ}

1. Квасницккий В.Ф. Сварка и пайка жаропрочных сплавов в судостроении / В.Ф. Квасницкий. Л.: Судостроение, 1986.

2. ЕаАс. Ч.T. Суперсплавы II: Жаропрочные материаль для аэрокосмических и промышленных энергоустановок / Ч.T. Симс, Н.С. Столофф, У.К. Хагель. М.: Металлургия, 1995. Т.1.

3. В8ндов Е.Н. Стратегические направления развития материалов и технологий их переработки на период до 2030 года / Е.Н. Каблов // Авиационные материаль и технологии. 2012. № 8. C. 7-17.

4. Вибір легуючого комплексу нового корозійного сплаву для соплових лопаток ГТД / I.І. Максюта, Ю.Г. Кваснииька, О.В. Михнян // Металознавство та обробка матеріалів. 2013. № 2. C. 29-34.

5. Квасницький В.Ф. Фізико-хімічні процеси при паянні жароміцних сплавів газових турбін / В.Ф. Квасницький, Г.Ф. Мяльниця, Ю.Г. Квасницька // Прогресивна техніка, технологія та інженерна освіта. У 2 m. Т.2: Матеріали ХІХ Міжнар. наук.техн. конф., присвяченій 120-річчю КПІ ім. Ігоря Сикорського та механіко машинобудівного ін.-ту. - 19-22 черв. 2018 р.,м. Киів, Украӥна. К.: КПІ ім. Ігоря Сікорського. Вид-во Політехніка», 2018. С.143-146. 
ВІСНИК

ОДЕСЬКОГО НАЦІОНАЛЬНОГО

МОРСЬКОГО УНІВЕРСИТЕТУ

№ 2 (59), 2019
HERALD

OF THE ODESSA NATIONAL

MARITIME UNIVERSITY

6. Обеспечение фазово-структурной стабильности высокохромистых жаропрочных сплавов для лопаток ГТУ / Мяльница, Максюта, Нейма // Металл и литьё. 2012. № 11. С.16-20.

7. Особенности технологии диффузионной пайки жаропрочного сплава ЭП 975 и литейного монокристаллического интерметаллидного сплава ВКНА-4У применительно к конструкции «Блиск»/В.И. Лукин, В.С. Рыльников, А.Н. Афанасьев-Ходькин, О.Б. Тимофеева // Сварочные производство. 2013.№ 7. C. 19-25.

8. Афанасьев-Ходыкин А.Н. Технология получения неразъемньх соединений из сплава ЖС 36 /А.Н. Афанасьев-Ходыкин, В.И. Лукин, В.С. Рыльников // Сварочное производство. 2010. № 7. С. 27-31.

9. Пайка в вакууме литого никелевого сплава ЖСбУ композиционными припоями на основе ВПр36. Ч. 1. / И.С. Малашенко, В.Е. Мазурак, Т.Н. Кушнарева и др. // Современная электрометаллургия. 2014. № 4. С. 49-58.

10. Куренкова В.В. Высокотемпературная пайка литейных жаропрочных никелевых сплавов борсодержашим припоем, легированным кремнием / В.В. Куренкова, И.С. Малашенко // Адгезия расплавов и пайка материалов. 2008. Bbin. 41. C. 63-87.

11. Кратковременная прочность и микроструктура паяньх соединений сплава ВЖЛ12У, полученных с использованием борсодержашчх припоев с присадкой кремния / И.С. Малашенко, В.В. Куренкова, А.Ф. Белявин и др. // Современная электрометаллургия. 2006. № 4. С.26-42.

\section{REFERECES}

1. Kvasnitskyi V.F. (1986). Svarka i payka zharoprochnykh splavov v sudostroyenii [Welding and brazing of heat-resistant alloys in shipbuilding]. Sudostroenie (Shipbuilding). - Leningrad, 224 p. (in Russian).

2. Sims C.T., Stoloff N.S., Hagel W.K. (1995). Supersplavy II: zharoprochnyye materialy dlya aerokosmicheskikh $i$ promyshlennykh energoustanovok [Superalloys II: heat-resistant materials for aerospace and industrial power plants]. Metallurgiya (Metallurgy). - Moscow, 384 (in Russian).

3. Myalnitsya G.P., Maksyuta I.I., Kvasnitska Yu.G, Mikhnyan O.V. (2013). Vibir leguyuchogo kompleksu novogo koroziynostiykogo splavu dlya soplovikh lopatok GTD [The choice of a new complex alloying corrosion-resistant alloy nozzle GTE blades]. Metal Science and Materials Processing, vol. 2, pp.29-34 (in Russian). 
4. Myalnitsya G.P., Maksyuta I.I., Kvasnitska Yu.G, Mikhnyan O.V., Neyma A.V. (2012). Obespecheniye fazovo-strukturnoy stabil'nosti vysokokhromistykh zharoprochnykh splavov dlya lopatok GTU [Ensuring phase-structural stability of high-chromium heatresistant alloys for GTU blades]. Metal and casting, vol.11, pp.16-20 (in Russian).

5. Lukin V.I., Rylnikov V.S., Afanasyev-Khodykin A.N., Timofeyeva O.B. (2013). Osobennosti tekhnologii diffuzionnoy payki zharoprochnogo splava EP 975 i liteynogo monokristallicheskogo intermetallidnogo splava VKNA-4U primenitel'no $k$ konstruktsii «Blisk» [Features of diffusion brazing technology of heat-resistant alloy EP 975 and casting single-crystal intermetallic alloy VKNA$4 U$ as applied to the «Blisk» design]. Welding production, vol. 7, pp.19-25 (in Russian).

6. Afanasyev-Khodykin A.N., Lukin V.I., Rylnikov V.S. (2010). Tekhnologiya polucheniya neraz'yemnykh soyedineniy iz splava ZHS 36 [The technology for the production of permanent joints from ZhS 36 alloy]. Welding production, vol.7, pp.27-31 (in Russian).

7. Malashenko I. S., Mazurak V. E., Kushnareva T. N., Kurenkova V. V., Zavidonov V. G., Yavdoshchina E. F. (2014). Payka v vakuume litogo nikelevogo splava ZHS6U kompozitsionnymi pripoyami na osnove VPr36. Chast 1 [Vacuum brazing of cast nickel alloy ZhS6U with composite solders based on VPr36. Part 1]. Modern electrometallurgy, vol. 4, pp. 49-58 (in Russian).

Стаття надійшла до редакиії 25.10.2019

\section{Рецензенти:}

доктор технічних наук, професор кафедри Фізики Національного університету кораблебудування ім. адм. Макарова О.О. Мочалов

кандидат технічних наук, доцент завідувач кафедри «Теорія i проектування корабля ім. проф. Ю.Л. Воробйова» Одеського національного морського університету О.В. Демідюк 